\title{
Purification of the gas after pyrolysis in coupled plasma-catalytic system
}

\author{
Michał Młotek*, Bogdan Ulejczyk, Joanna Woroszył, Irmina Walerczak, Krzysztof Krawczyk \\ Warsaw University of Technology, 3 Noakowskiego, 00-664 Warsaw, Poland \\ "Corresponding author: e-mail: mmlotek@ch.pw.edu.pl
}

\begin{abstract}
Gliding discharge and coupled plasma-catalytic system were used for toluene conversion in a gas composition such as the one obtained during pyrolysis of biomass. The chosen catalyst was G-0117, which is an industrial catalyst for methane conversion manufactured by INS Pulawy (Poland). The effects of discharge power, initial concentration of toluene, gas flow rate and the presence of the bed of the G-0117 catalyst on the conversion of $\mathrm{C}_{7} \mathrm{H}_{8}$, a model tars compounds were investigated. Conversion of coluene increases with discharge power and the highest one was noted in the coupled plasma-catalytic system. It was higher than that in the homogeneous system of gliding discharge. When applying a reactor with reduced G-0117 and $\mathrm{CO}(0.15 \mathrm{~mol} \%), \mathrm{CO}_{2}(0.15 \mathrm{~mol} \%), \mathrm{H}_{2}(0.30 \mathrm{~mol} \%)$, $\mathrm{N}_{2}(0.40 \mathrm{~mol} \%), 4000 \mathrm{ppm}$ of toluene and gas flow rate of $1.5 \mathrm{Nm}^{3} / \mathrm{h}$, the conversion of toluene was higher than 99\%. In the coupled plasma-catalytic system with G-0117 methanation of carbon oxides was observed.
\end{abstract}

Keywords: gliding discharge, non-equilibrium plasma, plasma-catalytic system, tar decompositio.

\section{INTRODUCTION}

Due to climate change and environmental hazards, it has become necessary to use renewable energy sources. One of them is biomass, which can be converted into a gaseous fuel ${ }^{1}$. Pyrolysis and gasification are two most common processes which convert chemical energy contained in biomass into useful energy, ${ }^{2,3}$. As a result of these processes carbon oxides and hydrogen are formed, which can be used as fuel to drive engines and turbines and for chemical synthesis. In these processes small amounts of tars are formed, which may deposit on the engine and turbine walls, what leads to lower efficiency of the process and may cause damage to these parts. ${ }^{4}$ The amount of tars in gas used as a feedstock for engines, according to different sources, must be no higher than $50-100 \mathrm{mg} / \mathrm{Nm}^{3}$ and $5 \mathrm{mg} / \mathrm{Nm}^{3}$ for turbines ${ }^{5}$. Therefore, the gas obtained in pyrolysis and gasification requires further purification ${ }^{4}$. The tars are mainly the complex mixture of condensable hydrocarbons, which includes single or multiple ring aromatic compounds also with oxygen, containing hydrocarbons and complex polycyclic aromatic hydrocarbons ${ }^{6}$. Such a mixture is very difficult to analysis, so it has been accepted in the scientific community that toluene or naphthalene was chosen as a model compound ${ }^{7-11}$.

Many gas cleaning processes have been proposed for the removal of tars from biomass gasification gas, including thermal cracking ${ }^{12,13}$, mechanical separation ${ }^{14,15}$ and catalytic reforming ${ }^{8-11}$. Thermal cracking process requires high temperatures $\left(>800^{\circ} \mathrm{C}\right)$ to decompose tars, and causes a high energy cost. Removal of tars from syngas with a physical separation process will decrease the overall processing efficiency. Catalytic reforming can convert tars into valuable products at relatively lower temperatures $\left(\sim 600^{\circ} \mathrm{C}\right)$ compared to thermal cracking process ${ }^{11}$. The best results were obtained in catalytic methods of gas purification, however because of unfavorable conditions of reactions, the catalysts were quickly deactivated ${ }^{16-19}$. Decomposition of tars was conducted on nickel based catalysts supported on $\mathrm{CaO}, \mathrm{MgO}$ and calcined dolomite, ceria-zirconia and a nickel-mayenite catalyst ${ }^{20-22}$. However, deactivation of the catalysts by poisoning or carbon deposits has been a major disadvantage for industrial applications. Adsorption on activated carbon, filtration, catalytic method and plasma techniques are the most studied methods for decomposition of tars.

Plasma of gliding discharge and a plasma-catalytic system has also been used for the conversion of toluene ${ }^{23,24}$. In the coupled plasma-catalytic system high conversion of toluene was obtained ${ }^{25}$. It may suggest that the use of active catalysts coupled with plasma of gliding discharge can lead to a higher conversion of tars and the activity of the catalysts could be stable.

The purpose of this work was to investigate the effects of power of discharge, initial concentration of toluene and the presence of the reduced form of the G-0117 catalyst on the conversion of $\mathrm{C}_{7} \mathrm{H}_{8}$.

\section{EXPERIMENTAL}

In the course of this work the conversion of toluene, a model tars compound, was studied. The study was conducted in homogeneous and heterogeneous plasma-catalytic systems with G-0117, an industrial catalyst for methane conversion synthesis, in the reduced form. Measurements were conducted for two gas flow rates 1.0 $\mathrm{Nm}^{3} / \mathrm{h}$ (2000 and $6000 \mathrm{ppm}$ of toluene) and $1.5 \mathrm{Nm}^{3} / \mathrm{h}$ (1000 and $2000 \mathrm{ppm}$ of toluene) in a homogeneous system and in a heterogeneous coupled plasma-catalytic system with a flow rate $1.5 \mathrm{Nm}^{3} / \mathrm{h}(2000$ and $4000 \mathrm{ppm}$ of toluene). The composition of the inlet stream was: $\mathrm{CO}(0.15 \mathrm{~mol} \%), \mathrm{CO}_{2}(0.15 \mathrm{~mol} \%), \mathrm{H}_{2}(0.30 \mathrm{~mol} \%)$, $\mathrm{N}_{2}(0.40 \mathrm{~mol} \%)$. The calorific value of this gas was c.a. $5.8 \mathrm{MJ} / \mathrm{m}^{3}$.

The conversion of toluene was investigated in a three-phase gliding discharge reactor under normal pressure. The reactor was made of a quartz-glass tube of 60 $\mathrm{mm}$ in diameter and was equipped with three converging duralumin electrodes. The gas inlet was located at the bottom, between the electrodes. The power supply consisted of ferroresonant transformers and a transistor inverter, which resulted in a poly-phase multi-electrode reactor system. The electric power supplied to the gliding reactor was in the range of $1-2 \mathrm{~kW}$ and was measured by an energy meter. The reactor and the power system were described previously ${ }^{26-28}$.

The gas temperature measured at the vessel axis over the upper ends of the electrodes reached $160-540^{\circ} \mathrm{C}$. 
It exhibits a dependence on the discharge power and presence of catalyst.

Two kinds of gas chromatographs were used for gas analysis: a Thermo-Scientific Trace 1300 instrument with a HP5 column and a Flame Ionized Detector (FID) to determine the toluene concentration and a mass spectrometer for other higher than C5 hydrocarbons analysis, and an Agilent $6890 \mathrm{~N}$ instrument with a ShinCarbon column and the following detectors: TCD and FID for the following gases: $\mathrm{CO}_{2}, \mathrm{CO}, \mathrm{H}_{2}, \mathrm{~N}_{2}, \mathrm{O}_{2}, \mathrm{CH}_{4}$ and $\mathrm{C} 2$ hydrocarbons analysis. The water vapor content was measured by an APAR moisture meter.

Toluene conversion was calculated using the equation:

$\mathrm{x}\left[\mathrm{C}_{7} \mathrm{H}_{8}\right]=\frac{\mathrm{W}_{0}\left[\mathrm{C}_{7} \mathrm{H}_{8}\right]-\mathrm{W}\left[\mathrm{C}_{7} \mathrm{H}_{8}\right]}{\mathrm{W}_{0}\left[\mathrm{C}_{7} \mathrm{H}_{8}\right]}$

where: $x\left[\mathrm{C}_{7} \mathrm{H}_{8}\right]$ - overall conversion of toluene;

$\mathrm{W}_{0}\left[\mathrm{C}_{7} \mathrm{H}_{8}\right] / \mathrm{mol} \cdot \mathrm{h}^{-1}, \mathrm{~W}\left[\mathrm{C}_{7} \mathrm{H}_{8}\right] / \mathrm{mol} \cdot \mathrm{h}^{-1}$ - toluene flow rate at the inlet and outlet respectively.

The calorific value of the fresh and outlet gas was calculated from the formula:

$\mathrm{W}=\frac{\Sigma \mathrm{Q}_{\mathrm{P}} \mathrm{i} \times \mathrm{a}_{\mathrm{i}}}{1000}$

where:

$\mathrm{W}$ - calorific value $\left[\mathrm{MJ} / \mathrm{m}^{3}\right]$

$\mathrm{i}-\mathrm{H}_{2}, \mathrm{CO}, \mathrm{CO}_{2}, \mathrm{CH}_{4}, \mathrm{C}_{2} \mathrm{H}_{2}, \mathrm{C}_{2} \mathrm{H}_{4}, \mathrm{C}_{2} \mathrm{H}_{6}$,

$\mathrm{Q}_{\mathrm{Pi}}$ - heat of combustion of the specific gas $\left[\mathrm{kJ} / \mathrm{m}^{3}\right]$

$a_{i}-$ molar fraction of the specific gas
The $\mathrm{X}$ - ray diffraction (XRD) analysis was carried out with a Seifert 3003 diffractometer (GE Inspection Technologies) using $\mathrm{CuK} \alpha$ radiation.

The specific surface area of the catalyst prior to and after the catalytic tests was determined using an ASAP2020 instrument (Micromeritics).

\section{Preparation of the catalyst}

For the experiments a bed of reduced G-0117 was used. The results of our previous studies were taken into account during the selection of the catalyst. To obtain catalyst particles suitable for our studies, the industrial catalyst was crushed and the fraction 1.6-3.15 mm was used. The catalyst was reduced for 4 hours at $400^{\circ} \mathrm{C}$ in hydrogen $(20 \mathrm{Nl} / \mathrm{h})$ and cooled in this atmosphere. The catalyst particles were packed into the reactor in a single batch of $36 \mathrm{ml}$. The height of the bed was $1.5 \mathrm{~mm}$. The specific surface area of G-0117 was 3.06 before and 3.46 $\mathrm{m}^{2} / \mathrm{g}$ after activity measurements.

The catalyst did not change during the activity measurements. Carbon deposits were not formed. The XRD analysis (Fig. 1) showed nickel as the main component of catalyst, it was not oxidized during experiments. $\mathrm{NiO}$ signals after measurements haven't been detected. Other signals originated from the support of the catalyst mainly alumina (corundum) and hibonit $\left(\mathrm{CaO}\left(\mathrm{Al}_{2} \mathrm{O}_{3}\right)_{3}\right)$.

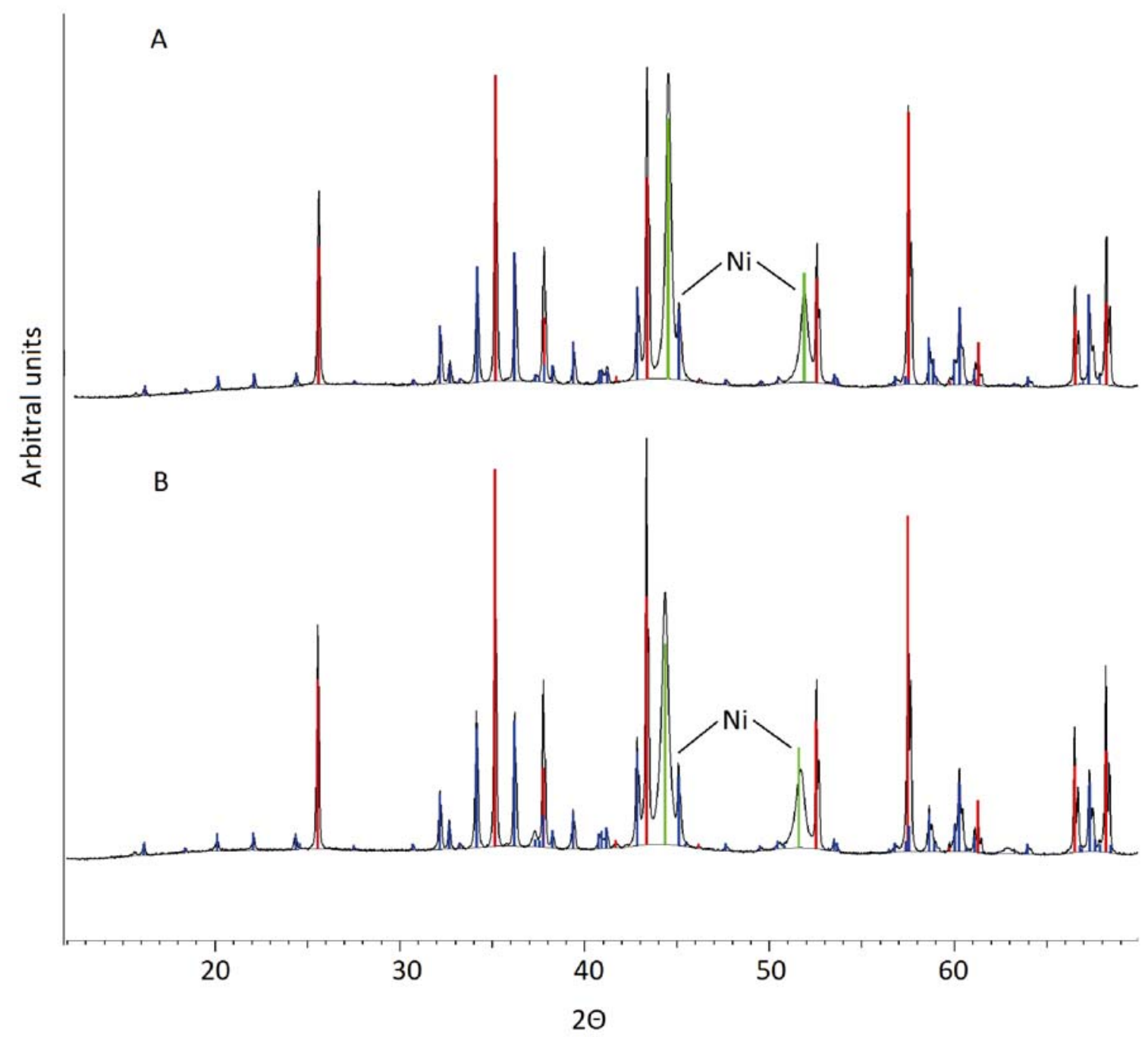

Figure 1. G-0117 catalyst structure before - A, and after measurements - B 


\section{RESULTS AND DISCUSSION}

The measurements of toluene decomposition were performed in a homogeneous (with gliding discharge plasma) and a coupled plasma-catalytic system (gliding discharge plasma and reduced G-0117 catalyst). The study was carried out in a stream containing carbon oxides, nitrogen and hydrogen for two gas flow rates $1.0 \mathrm{Nm}^{3} / \mathrm{h}$ (2000 and $6000 \mathrm{ppm}$ of toluene) and $1.5 \mathrm{Nm}^{3} / \mathrm{h}(1000$ and $2000 \mathrm{ppm}$ of toluene) in a homogeneous system and in a heterogeneous coupled plasma-catalytic system with a flow rate $1.5 \mathrm{Nm}^{3} / \mathrm{h}$ (2000 and $4000 \mathrm{ppm}$ of toluene). The composition of the inlet gas was (in molar fractions): $\mathrm{CO}(0.15), \mathrm{CO}_{2}(0.15), \mathrm{H}_{2}(0.30), \mathrm{N}_{2}(0.40)$. In the gas before the measurement, oxygen was not found, and the humidity was approx. $2 \%$. The obtained results are presented in Tables 1-3 and Figures 2 and 3.

In the homogeneous system the toluene conversion increases with the increase of initial concentration of $\mathrm{C}_{7} \mathrm{H}_{8}$ and with increasing power (Table 1 and Fig. 2) when the gas flow rate is fixed at $1000 \mathrm{Nl} / \mathrm{h}$. At high concentration of toluene, locally the temperature may increased due to toluene oxidation. This increase the reaction rate of $\mathrm{CO}_{2}$ decomposition ${ }^{7}$ (reaction 1).

$\mathrm{CO}_{2}+\mathrm{e}^{*} \rightarrow \mathrm{CO}+\mathrm{O}+\mathrm{e}$

The more oxygen radicals and high temperature leads to increase the toluene decomposition reactions rates.

In the outlet gas the presence of the following components was observed: $\mathrm{CO}_{2}, \mathrm{CO}, \mathrm{H}_{2}, \mathrm{CH}_{4}$, oxygen, $\mathrm{C} 2-\mathrm{C} 3$ hydrocarbons, $\mathrm{H}_{2} \mathrm{O}$ and trace amounts of $\mathrm{C} 4$

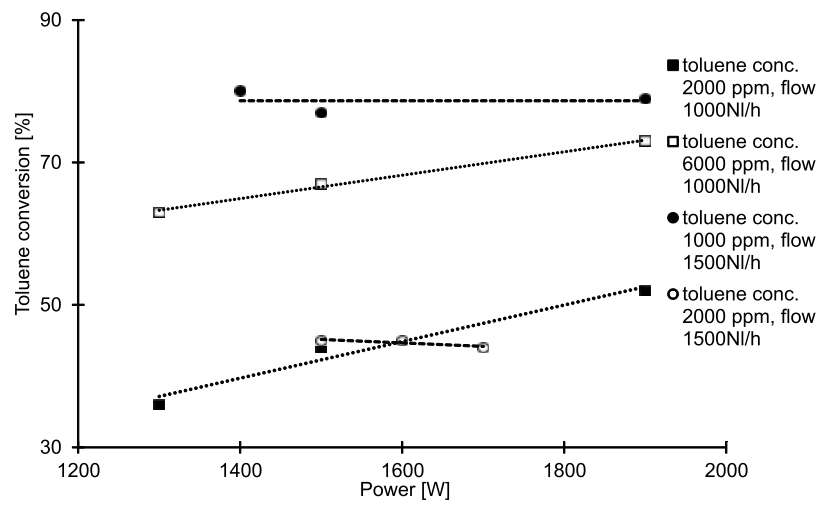

Figure 2. Toluene conversion in the homogeneous system

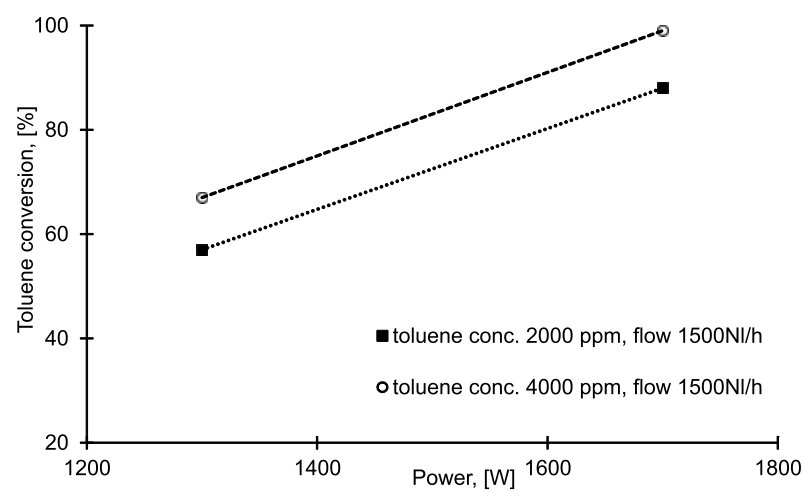

Figure 3. Toluene conversion in the plasma-catalytic system

Table 1. Results of toluene decomposition in the homogeneous system. Gas flow rate $1 \mathrm{Nm}^{3} / \mathrm{h}$

\begin{tabular}{|c|c|c|c|c|c|c|c|c|c|c|c|c|c|c|}
\hline \multirow{2}{*}{$\stackrel{P}{\mathrm{P}}$} & \multirow{2}{*}{$\begin{array}{l}\mathrm{Ed} \\
\mathrm{kJ} / \mathrm{l}\end{array}$} & \multirow{2}{*}{$\begin{array}{c}\mathrm{T}_{\mathrm{R}} \\
{\left[{ }^{\circ} \mathrm{C}\right]}\end{array}$} & \multirow{2}{*}{$\begin{array}{c}\mathrm{H} . \\
{[\%]}\end{array}$} & \multirow{2}{*}{$\begin{array}{c}\mathrm{X}_{\mathrm{C7H8} 8} \\
{[\%]}\end{array}$} & \multicolumn{9}{|c|}{ Molar fraction } & \multirow{2}{*}{$\begin{array}{l}\text { Calorific } \\
\text { value } \\
{\left[\mathrm{MJ} / \mathrm{m}^{3}\right]}\end{array}$} \\
\hline & & & & & $\mathrm{H}_{2}$ & $\mathrm{O}_{2}$ & $\mathrm{~N}_{2}$ & $\mathrm{CO}$ & $\mathrm{CO}_{2}$ & $\mathrm{CH}_{4}$ & $\mathrm{C}_{2} \mathrm{H}_{2}$ & $\mathrm{C}_{2} \mathrm{H}_{4}$ & $\mathrm{C}_{2} \mathrm{H}_{6}$ & \\
\hline \multicolumn{15}{|c|}{$2000 \mathrm{ppm}$ of toluene } \\
\hline 1300 & 4.7 & 200 & 68.6 & 36 & 0.313 & 0.017 & 0.322 & 0.201 & 0.132 & 0.010 & 0.004 & 0.001 & 0.001 & 7.35 \\
\hline 1500 & 5.4 & 290 & 80.0 & 44 & 0.254 & 0.038 & 0.367 & 0.197 & 0.128 & 0.010 & 0.004 & 0.001 & 0.001 & 6.54 \\
\hline 1900 & 6.8 & 345 & 84.5 & 52 & 0.299 & 0.030 & 0.319 & 0.219 & 0.115 & 0.011 & 0.004 & 0.001 & 0.002 & 7.51 \\
\hline \multicolumn{15}{|c|}{$6000 \mathrm{ppm}$ of toluene } \\
\hline 1300 & 4.7 & 169.5 & 56.5 & 63 & 0.310 & 0.015 & 0.331 & 0.193 & 0.137 & 0.006 & 0.006 & 0.001 & 0.001 & 7.17 \\
\hline 1500 & 5.4 & 257.4 & 61.6 & 67 & 0.262 & 0.031 & 0.369 & 0.193 & 0.130 & 0.006 & 0.006 & 0.002 & 0.001 & 6.61 \\
\hline 1900 & 6.8 & 324.5 & 81.5 & 73 & 0.287 & 0.019 & 0.344 & 0.213 & 0.122 & 0.007 & 0.007 & 0.002 & 0.001 & 7.29 \\
\hline
\end{tabular}

Table 2. Results of toluene decomposition in the homogeneous system. Gas flow rate $1.5 \mathrm{Nm}^{3} / \mathrm{h}$

\begin{tabular}{|c|c|c|c|c|c|c|c|c|c|c|c|c|c|c|}
\hline \multirow{2}{*}{$P[W]$} & \multirow{2}{*}{$\begin{array}{c}\mathrm{Ed} \\
\mathrm{kJ} / \mathrm{l}\end{array}$} & \multirow{2}{*}{$\begin{array}{c}\mathrm{T}_{\mathrm{R}} \\
{\left[{ }^{\circ} \mathrm{C}\right]}\end{array}$} & \multirow{2}{*}{$\begin{array}{l}\mathrm{H} . \\
{[\%]}\end{array}$} & \multirow{2}{*}{$\begin{array}{c}\mathrm{X}_{\mathrm{C} 7 \mathrm{H} 8} \\
{[\%]}\end{array}$} & \multicolumn{9}{|c|}{ Molar fraction } & \multirow{2}{*}{$\begin{array}{c}\text { Calorific } \\
\text { value } \\
{\left[\mathrm{MJ} / \mathrm{m}^{3}\right]}\end{array}$} \\
\hline & & & & & $\mathrm{H}_{2}$ & $\mathrm{O}_{2}$ & $\mathrm{~N}_{2}$ & $\mathrm{CO}$ & $\mathrm{CO}_{2}$ & $\mathrm{CH}_{4}$ & $\mathrm{C}_{2} \mathrm{H}_{2}$ & $\mathrm{C}_{2} \mathrm{H}_{4}$ & $\mathrm{C}_{2} \mathrm{H}_{6}$ & \\
\hline \multicolumn{15}{|c|}{$1000 \mathrm{ppm}$ of toluene } \\
\hline 1400 & 3.4 & 200 & 68.6 & 80 & 0.305 & 0.019 & 0.346 & 0.173 & 0.150 & 0.010 & 0.006 & 0.001 & 0.000 & 6.94 \\
\hline 1500 & 3.6 & 290 & 80.0 & 77 & 0.278 & 0.028 & 0.367 & 0.175 & 0.143 & 0.010 & 0.007 & 0.001 & 0.00 & 6.68 \\
\hline 1900 & 4.6 & 345 & 84.5 & 79 & 0.268 & 0.030 & 0.374 & 0.179 & 0.139 & 0.011 & 0.007 & 0.001 & 0.000 & 6.64 \\
\hline \multicolumn{15}{|c|}{$2000 \mathrm{ppm}$ of toluene } \\
\hline 1500 & 3.4 & 139 & 51.0 & 45 & 0.215 & 0.067 & 0.465 & 0.115 & 0.127 & 0.007 & 0.002 & 0.001 & 0.001 & 4.76 \\
\hline 1600 & 3.6 & 243 & 62.1 & 45 & 0.288 & 0.030 & 0.424 & 0.095 & 0.149 & 0.009 & 0.002 & 0.001 & 0.002 & 5.60 \\
\hline 1700 & 4.6 & 296.6 & 69.8 & 44 & 0.280 & 0.038 & 0.457 & 0.057 & 0.155 & 0.009 & 0.002 & 0.001 & 0.002 & 5.02 \\
\hline
\end{tabular}

Table 3. Results of toluene decomposition in the coupled plasma-catalytic system. Gas flow rate $1.5 \mathrm{Nm}^{3} / \mathrm{h}$

\begin{tabular}{|c|c|c|c|c|c|c|c|c|c|c|c|c|c|c|}
\hline \multirow[b]{2}{*}{$P[W]$} & \multirow{2}{*}{$\begin{array}{c}\mathrm{Ed} \\
\mathrm{kJ} / \mathrm{l}\end{array}$} & \multirow{2}{*}{$\begin{array}{c}\mathrm{T}_{\mathrm{R}} \\
{\left[{ }^{\circ} \mathrm{C}\right]}\end{array}$} & \multirow{2}{*}{$\begin{array}{l}\mathrm{H} . \\
{[\%]}\end{array}$} & \multirow{2}{*}{$\begin{array}{c}\mathrm{X}_{\mathrm{C7H8}} \\
{[\%]}\end{array}$} & \multicolumn{9}{|c|}{ Molar fraction } & \multirow{2}{*}{$\begin{array}{l}\text { Calorific } \\
\text { value } \\
{\left[\mathrm{MJ} / \mathrm{m}^{3}\right]}\end{array}$} \\
\hline & & & & & $\mathrm{H}_{2}$ & $\mathrm{O}_{2}$ & $\mathrm{~N}_{2}$ & $\mathrm{CO}$ & $\mathrm{CO}_{2}$ & $\mathrm{CH}_{4}$ & $\mathrm{C}_{2} \mathrm{H}_{2}$ & $\mathrm{C}_{2} \mathrm{H}_{4}$ & $\mathrm{C}_{2} \mathrm{H}_{6}$ & \\
\hline \multicolumn{15}{|c|}{$2000 \mathrm{ppn}$ of toluene } \\
\hline 1300 & 3.1 & 240 & 79 & 57 & 0.289 & 0.011 & 0.331 & 0.212 & 0.137 & 0.011 & 0.001 & 0.000 & 0.000 & 6.91 \\
\hline 1700 & 4.1 & 540 & 30 & 88 & 0.185 & 0.026 & 0.415 & 0.318 & 0.172 & 0.055 & 0.004 & 0.000 & 0.000 & 8.83 \\
\hline \multicolumn{15}{|c|}{$4000 \mathrm{ppm}$ of toluene } \\
\hline 1300 & 3.1 & 240 & 64 & 67 & 0.236 & 0.0 & 0.353 & 0.150 & 0.188 & 0.061 & 0.000 & 0.000 & 0.000 & 7.37 \\
\hline 1700 & 4.1 & 540 & 100 & 99 & 0.165 & 0.019 & 0.414 & 0.120 & 0.183 & 0.072 & 0.004 & 0.000 & 0.000 & 6.74 \\
\hline
\end{tabular}


hydrocarbons. Generally, the molar fraction of the main compounds was similar for both initial concentrations of toluene (Table 1). The methane content for the initial concentration of toluene equal to $2000 \mathrm{ppm}$ was higher than that for $6000 \mathrm{ppm}$. It was $0.010-0.011$ and $0.006-$ -0.007 for 2000 and $6000 \mathrm{ppm}$, respectively. In the outlet gas the acetylene content was about $50 \%$ higher for the higher toluene content. For both initial concentrations of toluene the molar fractions of ethylene and ethane were the same. The concentration of hydrocarbons above C3 and $\mathrm{C} 4$ does not exceed $20 \mathrm{ppm}$.

For the gas flow rate of $1.5 \mathrm{Nm}^{3} / \mathrm{h}$ and the initial concentration of toluene of $2000 \mathrm{ppm}$ the conversion of $\mathrm{C}_{7} \mathrm{H}_{8}$ did not depend on the power (Fig. 2). It can be result of short residence time and consumption of the excited electrons generated in plasma on other processes i.e carbon dioxide dissociation and formation of oxygen radicals. However high toluene conversion at concentration $1000 \mathrm{ppm}$ was the effect of reaction of oxygen radicals with toluene. Oxygen radicals may also recombine with each other to generate oxygen molecule. The highest toluene conversion $(80 \%)$ was noted for the initial concentration of toluene of $1000 \mathrm{ppm}$ and power of $1400 \mathrm{~W}$.

The amount of $\mathrm{CO}$ decreased as the discharge power increased and in the outlet gas a higher oxygen concentration than that for $1.0 \mathrm{Nm}^{3} / \mathrm{h}$ was detected.

The mass balance (Table 4) shows that for the homogeneous system the molar rates in the inlet and outlet streams were similar. The balance shows that nearly all products generated during the process have been quantified.

The calorific value of the outlet stream in the homogeneous system was lower while using a higher gas flow rate. The highest values were obtained in the plasma-catalytic system and the gas flow rate of $1.5 \mathrm{Nm}^{3} / \mathrm{h}$. It was $8.83 \mathrm{MJ} / \mathrm{m}^{3}$ for $1700 \mathrm{~W}$ and initial concentration

Table 4. Mass balance of carbon $[\mathrm{mol} / \mathrm{h}]$ in the homogeneous system. Gas flow rate $1.0 \mathrm{Nm}^{3} / \mathrm{h}$. Initial conc. of toluene $2000 \mathrm{ppm}$

\begin{tabular}{|l|c|c|c|c|}
\hline \multirow{2}{*}{ Compounds } & \multicolumn{4}{|c|}{$\mathrm{P}[\mathrm{W}]$} \\
\cline { 2 - 5 } & $0^{(*)}$ & 1300 & 1500 & 1900 \\
\hline $\mathrm{CO}$ & 7.37 & 8.97 & 8.79 & 9.78 \\
\hline $\mathrm{CO}_{2}$ & 7.05 & 5.89 & 5.71 & 5.13 \\
\hline $\mathrm{CH}_{4}$ & 0.00 & 0.44 & 0.43 & 0.46 \\
\hline $\mathrm{C}_{2} \mathrm{H}_{2}$ & 0.00 & 0.36 & 0.36 & 0.40 \\
\hline $\mathrm{C}_{2} \mathrm{H}_{4}$ & 0.00 & 0.08 & 0.08 & 0.08 \\
\hline $\mathrm{C}_{2} \mathrm{H}_{6}$ & 0.00 & 0.04 & 0.07 & 0.08 \\
\hline $\mathrm{C}_{7} \mathrm{H}_{8}$ & 0.62 & 0.40 & 0.35 & 0.30 \\
\hline$\Sigma$ & 15.02 & 16.18 & 15.79 & 15.83 \\
\hline
\end{tabular}

$\left.{ }^{*}\right)$ Initial composition of the inlet stream

of toluene $2000 \mathrm{ppm}$. It shows that the coupled system enhanced the calorific value of the outlet gas.

On the basis of the obtained results (Table 3) it was found that for the reduced catalyst, the $\mathrm{CO}$ concentration decreases by about $25 \%$ and the hydrogen concentration decreases by about $43 \%$ in $4000 \mathrm{ppm}$ concentration of toluene. This is probably due to multiple reactions occurring during the process. These may be, for example, oxidation reactions, reduction, conversion, dissociation and methanation ${ }^{4}$. The use of the catalyst has resulted in a much higher efficiency of the removal of toluene, the model substance of tars in the gas after biomass pyrolysis (Fig. 3). It should be noted, however, that the use of a catalyst causes a significant reduction in the amount of hydrogen in the outlet gas. In the case of homogeneous systems, the hydrogen content is reduced, on average, by about $12 \%$, and under the same conditions in the plasma catalytic system the hydrogen content decreases by up to $43 \%$. Similarly, an unfavorable phenomenon was observed with the amount of carbon monoxide. In the homogeneous system, the amount of $\mathrm{CO}$ increased and in the plasma-catalytic system it decreased by about $20 \%$ for the discharge power of $1700 \mathrm{~W}$. Based on the results of the tests it was found that the total decomposition of toluene is possible in a G-0117 catalytic converter with the reduced form of the catalyst.

The use of the plasma - catalyst system increased the calorific value of the outlet gas. It was higher than the calorific value of the inlet gas and above the minimal level demanded by engines and turbines. One can conclude that some part of energy consumed for plasma generation was recuperated in the increase of calorific value of the outlet gas.

\section{CONCLUSIONS}

On the basis of the obtained results it has been found that the application of the gliding discharge is an effective technique for decomposition of toluene, a model compound for tar produced in biomass gasification. The obtained results were repeatable and by mass balance it can be concluded that most of the products were determined. The conversion of toluene increased with discharge power. The highest efficiency of toluene decomposition and calorific rate of outlet gas were obtained in the plasma-catalytic system with the reduced G-0117 catalyst.

\section{ACKNOWLEDGMENT}

This work was supported by the National Center for Research and Development agreement no PBS2/ A1/10/2013.

\section{LITERATURE CITED}

1. Nahar, G., Mote, D. \& Dupont, V. (2017). Hydrogen production from reforming of biogas Review of technological advances and an Indian perspective. Renew. Sust. Energ. Rev. 76, 1032-1052. DOI: 10.1016/j.rser.2017.02.031.

2. Molino, A., Chianese, S. \& Musmarra, D. (2016). Biomass gasification technology The state of the art overview. $J$. Energy. Chem. 25, 10-25. DOI: 10.1016/j.jechem.2015.11.005.

3. Hossain, M.A., Jewaratnam, J. \& Ganesan, P. (2016). Prospect of hydrogen production from oil palm biomass by thermochemical process - A review. Int. J. Hydrogen. Energ. 41, 16637-6655. DOI: 10.1016/j.ijhydene.2016.07.104.

4. Chan, F.L. \& Tanksale, A. (2014). Review of recent developments in Ni-based catalysts for biomass gasification. Renew. Sust. Energ. Rev. 38, 428-438. DOI: 10.1016/j.rser.2014.06.011.

5. Anis, S. \& Zainal, Z.A. (2011). Tar reduction in biomass producer gas via mechanical. catalytic and thermal methods - A review. Renew. Sust. Energ. Rev. 15, 2355-2377. DOI: 10.1016/j.rser.2011.02.018. 
6. Devi, L., Ptasinski, K.J. \& Janssen, F.J.J.G. (2005). Decomposition of naphthalene as a biomass tar over pretreated olivine: Effect of gas composition, kinetic approach, and reaction scheme. Ind. Eng. Chem. Res. 44, 9096-9104. DOI: $10.1021 / \mathrm{ie} 050801 \mathrm{~g}$.

7. Zhao, B., Zhang, X., Chen, L., Qu, R., Meng, G., Yi, X. \& Sun, L. (2010) Steam reforming of toluene as model compound of biomass pyrolysis tar for hydrogen. Biomass Bioenerg. 34, 140-144. DOI: 10.1016/j.biombioe.2009.10.011.

8. Noichi, H., Uddin, A. \& Sasaoka, E. (2010). Steam reforming of naphthalene as model biomass tar over iron-aluminum and iron-zirconium oxide catalyst catalysts, Fuel Process. Technol. 91, 1609-1616. DOI: 10.1016/j.fuproc.2010.06.009.

9. Kong, M., Fei, J.H., Wang, S.A., Lu, W. \& Zheng, X.M. (2011). Influence of supports on catalytic behavior of nickel catalysts in carbon dioxide reforming of toluene as a model compound of tar from biomass gasification, Bioresour. Technol. 102, 2004-2008. DOI: 10.1016/j.biortech.2010.09.054.

10. Zhang, R.Q., Wang, H.J. \& Hou, X.X. (2014). Catalytic reforming of toluene as tar model compound: effect of $\mathrm{Ce}$ and $\mathrm{Ce}-\mathrm{Mg}$ promoter using Ni/olivine catalyst. Chemosphere. 97, 40-46. DOI: 10.1016/j.chemosphere.2013.10.087.

11. Świerczyński, D., Libs, S., Courson, C. \& Kiennemann, A. (2007). Steam reforming of tar from a biomass gasification process over $\mathrm{Ni} /$ olivine catalyst using toluene as a model compound. Appl. Catal. B, 74, 211-222. DOI: 10.1016/j. apcatb.2007.01.017.

12. Ni, M., Leung, D.Y.C., Leung, M.K.H. \& Sumathy, K. (2006). An overview of hydrogen production from biomass. Fuel Process Technol. 87, 461-472. DOI: 10.1016/j. fuproc.2005.11.003.

13. Fagbemi, L., Khezami, L. \& Capart, R. (2001). Pyrolysis products from different biomasses: application to the thermal cracking of tar. Appl. Energy. 69, 293-306. DOI: 10.1016/ S0306-2619(01)00013-7.

14. Pathak, B.S., Kapatel, D.V., Bhoi, P.R., Sharma, A.M. \& Vyas, D.K. (2007). Design and development of sand bed filter for upgrading producer gas to IC engine quality fuel. Int. Energy J. 8, 15-20. DOI: 10.1063/1.4791590.

15. Bhave, A.G., Vyas, D.K. \& Patel, J.B. (2008). Wet packed bed scrubber-based producer gas cooling-cleaning system. Renew. Energ. 33, 1716-1720. DOI: 10.1016/j.renene.2007.08.014.

16. Shen, Y. \& Yoshikawa, K. (2013). Recent progresses in catalytic tar elimination during biomass gasification. Renew. Sust. Energ. Rev. 21, 371-392. DOI: 10.1016/j.rser.2012.12.062.

17. Park, J. Lee, Y. \& Ryu, C. (2016). Reduction of primary tar vapor from biomass by hot char particles in fixed bed gasification. Biomass. Bioenerg. 90, 114-121. DOI: 10.1016/j. biombioe.2016.04.001.

18. Tuomi, S. Kurkela, E. Simell, P. \& Reinikainen, M. (2015). Behaviour of tars on the filter in high temperature filtration of biomass-based gasification gas. Fuel 139, 220-231. DOI: 10.1016/j.fuel.2014.08.051.

19. Liu, X. Yang, X. Liu, C. Chen, P. Yue, X. \& Zhang, S. (2016). Low-temperature catalytic steam reforming of toluene over activated carbon supported nickel catalysts. J. Taiwan. Inst. Chem. E. 65, 233-241. DOI: 10.1016/j.jtice.2016.05.006.

20. Di Felice, L., Courson, C., Foscolo, P.U. \& Kiennemann, A. (2011). Iron and nickel doped alkaline-earth catalysts for biomass gasification with simultaneous tar reformation and $\mathrm{CO}_{2}$ capture. Int. J. Hydrogen. Energ. 36, 5296-5310. DOI: 10.1016/j.ijhydene.2011.02.008.

21. Łamacz, A., Krzton, A. \& Djega-Mariadassou, G. (2011). Steam reforming of model gasification tars compounds on nickel based ceria-zirconia catalysts. Catal. Today 17, 347-351. DOI: 10.1016/j.cattod.2010.11.067.

22. Di Carlo, D.A., Borello, D., Sisinni, M., Savuto, E., Venturini, P., Bocci, E. \& Kuramoto, K. (2015). Reforming of tar contained in a raw fuel gas from biomass gasification using nickel-mayenite catalyst. Int. J. Hydrogen. Energ. 40, 9088-9095. DOI: 10.1016/j.ijhydene.2015.05.128.

23. Tao, K., Ohta, N., Liu, G., Yoneyama, Y., Wang, T. \& Tsubaki, N. (2013). Plasma enhanced catalytic reforming of biomass tar model compound to syngas. Fuel. 104, 53-57. DOI: 10.1016/j.fuel.2010.05.044.

24. Liu, S., Mei, D., Wang, L. \& Tu, X. (2017). Steam reforming of toluene as biomass tar model compound in a gliding arc discharge reactor. Chem. Eng. J. 307, 793-802. DOI: 10.1016/j.cej.2016.08.005.

25. Nadziakiewicz, J., Pikoń, K. \& Stelmach, S. (2012). Oczyszczanie gazu syntezowego z zanieczyszczeń węglowodorowych w reaktorze plazmowo-katalitycznym. Przem. Chem. 91, 1270-1274.

26. Młotek, M., Reda, E., Jóźwik, P., Krawczyk, K. \& Bojar, Z. (2015). Plasma-catalytic decomposition of cyclohexane in gliding discharge reactor. Appl. Catal. A-Gen. 505, 150-158. DOI: 10.1016/j.apcata.2015.07.033.

27. Młotek, M., Ulejczyk, B., Walerczak, I., Woroszył, J. \& Krawczyk, K. (2016). The $15^{\text {th }}$ International Symposium on High Pressure Low Temperature Plasma Chemistry Hakone XV, 11-16 September 2016 (pp. 245-248). Brno, Czech Republic. 28. Młotek, M., Ulejczyk, B., Woroszył, J. \& Krawczyk, K. (2017). $21^{\text {st }}$ Symposium on Applications of Plasma Processes. 13-18 January 2017 (pp. 236-240). Štrbské Pleso. Slovakia. 